\title{
Pemancar Modulasi Frekuensi dengan Modul GRF-3300
}

\author{
Budihardja Murtianta ${ }^{1}$, Deddy Susilo², Rizky Salenda ${ }^{3}$ \\ Program Studi Teknik Elektro, \\ Fakultas Teknik Elektronika dan Komputer, \\ Universitas Kristen Satya Wacana, Salatiga \\ 1budihardja.murtianta@staff.uksw.edu, 2deddy.susilo@staff.uksw.edu, \\ 3612011053@students.uksw.edu
}

\begin{abstract}
Ringkasan
Dalam era teknologi telekomunikasi, sistem pemancar (transmitter) dan sistem penerima (receiver) merupakan hal yang sangat mendasar. Pada tulisan ini dibahas sistem pemancar yang berperan untuk mengirim suatu sinyal informasi. Pengiriman informasi bisa lewat beberapa media transmisi, seperti serat optik, microwave, udara dan sebagainya. Pemancar ini mengirimkan sinyal informasi lewat udara dan terdiri dari : Modulator, mixer, PLL, preamplifier, attenuator, penguat daya dan antena. Pada tulisan ini dijelaskan cara kerja prinsip dasar sistem pemancar dengan dengan modul GRF-3300. Penguat daya mempunyai faktor penguatan daya yang jauh lebih besar dari pada preamplifier. Sinyal informasi yang dikirim lewat pemancar akan diterima kembali seperti bentuk semula.
\end{abstract}

Kata kunci: transmitter, mixer, modulator

\section{Pendahuluan}

Teknik telekomunikasi merupakan salah satu cabang ilmu pengetahuan yang mempelajari cara pembangkitan, pengolahan, penyaluran, dan penyebaran data atau informasi menggunakan media kabel (wire) atau tanpa kabel (wireless) untuk jarak jauh. Di era sekarang ini, telekomunikasi merupakan hal yang sangat dekat dengan manusia, dikarenakan mobilitas masyarakat yang berpindah-pindah ke tempat yang jauh. Dengan alasan itu, perkembangan teknik telekomunikasi saat ini terbilang laku dipasaran, oleh karenanya banyak orang yang tertarik untuk mempelajari lebih lagi mengenai teknik telekomunikasi. Pada tulisan ini akan dibahas tentang pemancar modulasi frekuensi dengan modul GRF-3300 yang merupakan salah satu alat untuk menganalisa bagian transmitter dan receiver frekuensi tinggi pada aplikasi nirkabel. Meski begitu, aplikasi transmitter tidaklah mudah untuk dimengerti begitu saja, perlu adanya penjelasan yang lebih mendalam akan bagian-bagian dari sebuah struktur sistem pemancar. Pada tulisan ini akan dijelaskan prinsip kerja dan komponen yang digunakan pada bagian-bagian dari sebuah sistem pemancar sehingga bisa membantu menjelaskan hal-hal terkait pada sebuah transmitter.

\section{Dasar Teori}

Pemancar (Transmitter) adalah sebuah alat untuk memancarkan suatu sinyal. Cara kerja pemancar secara sederhana yaitu menguatkan dan memodulasikan sinyal masukan 
lalu dialirkan ke antena untuk di ubah menjadi gelombang elektromaknetik. Parameter dari sebuah pemancar berupa : Rentang frekuensi, daya, efesiensi, dan derau. Struktur dasar transmisi ini berupa : Masukan, Modulator, PLL, preamplifier, penguat daya dan antena pemancar. Pada Gambar 1 adalah bagan kotak pemancar modul GRF-3300. Modulator berfungsi untuk memodulasikan frekuensi sinyal masukan menjadi frekuensi sinyal yang tepat. Mixer bertugas untuk mentransformasikan beberapa frekuensi. PLL (Phase Lock Loop) dipakai untuk menghasilkan frekuensi sinyal keluaran yang diinginkan dari frekuensi sinyal masukan. Preamplifier berfungsi sebagai penguat sinyal sebelum masuk attenuator. Attenuator merupakan komponen RF yang melemahkan aras sinyal. Penguat daya adalah penguat akhir sebelum dipancarkan lewat antena.

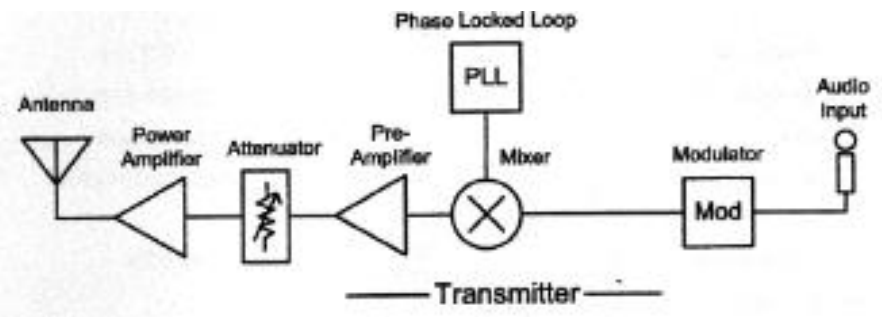

Gambar 1. Bagan kotak pemancar [1]

\section{Bagian-Bagian Pemancar}

Pada bagian ini akan dijelaskan bagian-bagian pembentuk pemancar dan fungsi dari tiap-tiap bagian. Selain itu juga diberikan rangkaian dari tiap bagian tersebut. Pemancar yang dibahas ini berupa modulasi frekuensi dan terdiri dari: modulator, mixer, PLL, preamplifier, attenuator, penguat daya dan antena. Gambar bagan kotak pemancar dapat dilihat pada Gambar 1.

\subsection{Modulator}

Fungsi modulator adalah untuk memodulasikan isyarat pembawa dengan frekuensi tinggi oleh isyarat informasi dengan frekuensi rendah. Tujuan utama modulasi adalah untuk membawa isyarat informasi yang mempunyai frekuensi rendah ke frekuensi tinggi tertentu sehingga tidak terjadi interferensi antara isyarat-isyarat dengan frekuensi rendah. Proses Modulasi Frekuensi (Frequency Modulation, FM) ditunjukkan pada Gambar 2 dan spektrum frekuensi ditunjukkan pada Gambar 3.

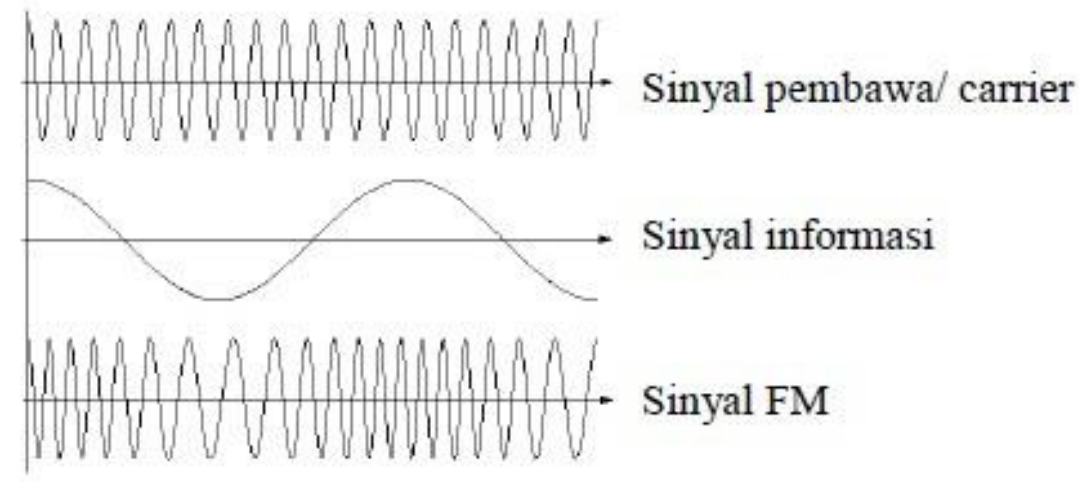

Gambar 2. Proses Modulasi Frekuensi[2] 


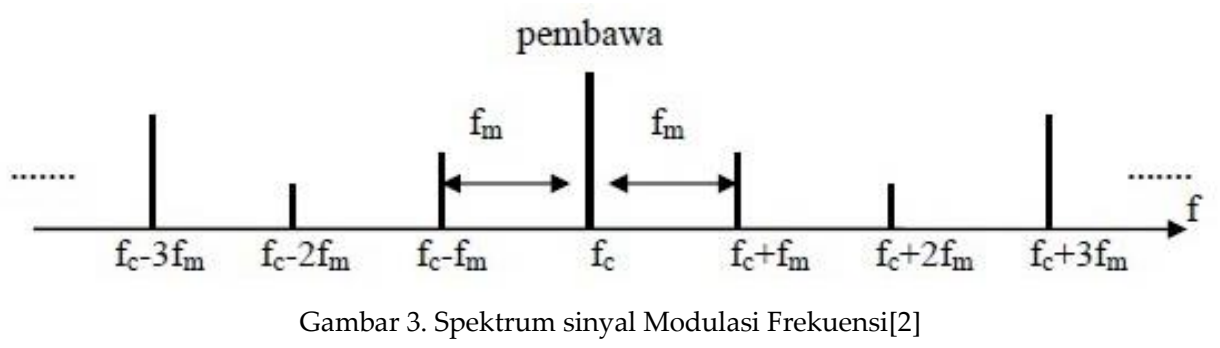

Persamaan sinyal $F M$ dapat dituliskan sebagai berikut:

$$
E_{f m}=E_{c} \sin \left(\omega_{c} t+m_{f} \sin \omega_{m} t\right)
$$

dimana,

$\mathrm{E}_{\mathrm{fm}}=$ nilai sesaat sinyal $F M$

$\mathrm{E}_{\mathrm{c}}$ = amplituda maksimum sinyal pembawa

$\omega_{c}=2 \pi f_{c}$ dengan $f_{c}$ adalah frekuensi sinyal pembawa

$\omega_{\mathrm{m}}=2 \pi \mathrm{f}_{\mathrm{m}}$ dengan $\mathrm{f}_{\mathrm{m}}$ adalah frekuensi sinyal pemodulasi

Pada modulasi frekuensi kita mengenal istilah indeks modulasi $\left(\mathrm{m}_{\mathrm{f}}\right)$. Indeks modulasi ini didefinisikan sebagai perbandingan antara simpangan frekuensi maksimum dengan frekuensi sinyal pemodulasi, dengan persamaan seperti berikut ini:

$$
m_{\mathrm{f}}=\Delta \mathrm{f} / \mathrm{f}_{\mathrm{m}}
$$

dimana,

$\mathrm{m}_{\mathrm{f}}=$ indeks modulasi frekuensi

$\Delta \mathrm{f}=$ deviasi frekuensi

$\mathrm{f}_{\mathrm{m}}=$ frekuensi sinyal pemodulasi

Gambar 4 menunjukan spektrum sinyal Modulasi Frekuensi dengan indeks modulasi ( $\mathrm{m} f)$ yang divariasikan dari 0,5 sampai 4 . Gambar 5 adalah rangkaian modulator yang dipergunakan.

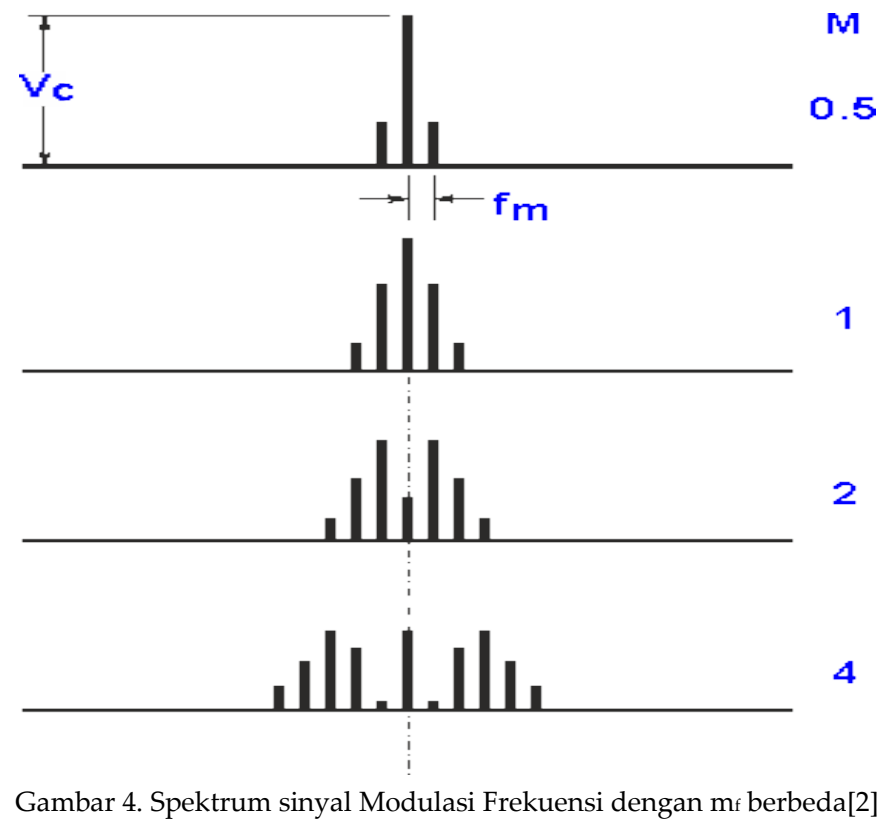




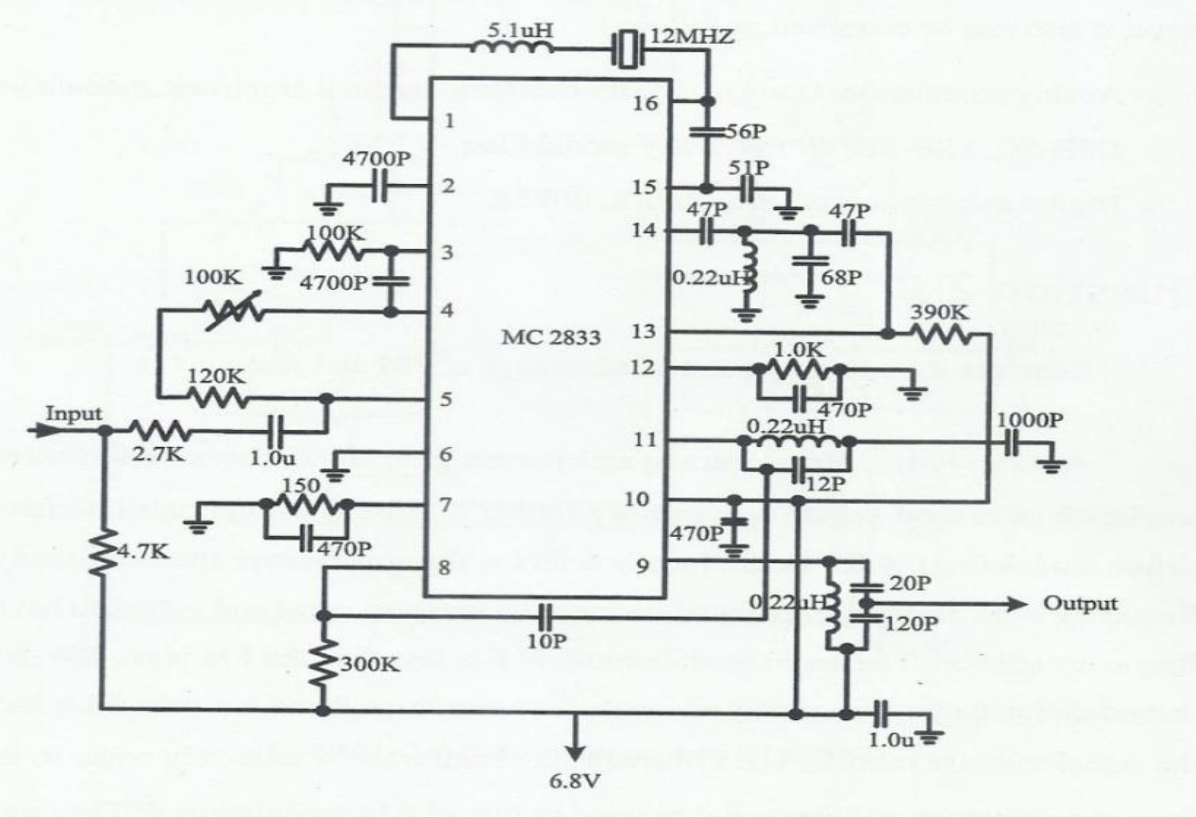

Gambar 5. Rangkaian modulator[1]

\section{2. $\quad$ Mixer}

Tujuan dari sebuah mixer adalah untuk mentransformasikan frekuensi. Sebagai contoh dalam sebuah sistem penerima, sebuah sinyal $R F$ akan dialihkan ke dalam sinyal intermediate untuk ditangani dalam rangkaian pita dasar. Dalam sistem pengirim sinyal pita dasar dialihkan ke sinyal $R F$ dan dikirim lewat antena, didorong oleh penguat daya. Sebuah mixer menggunakan komponen non-linier untuk mendapatkan efek transformasi frekuensi yang persis untuk rangkaian diode, dimana tegangan-arus $D C$ mempunyai karakteristik non-linier yang ditunjukkan pada Gambar 6.

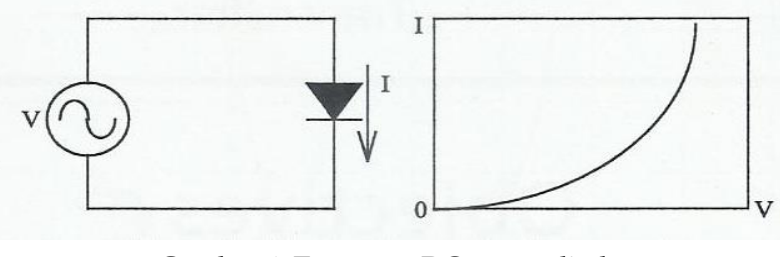

Gambar 6. Tegangan DC - arus diode

Hubungan ini bisa dinyatakan dengan penjelasan Taylor :[2]

$$
\mathrm{I}=\mathrm{a}_{0}+\mathrm{a}_{1} \mathrm{~V}+\mathrm{a}_{2} \mathrm{~V}^{2}+\mathrm{a}_{3} \mathrm{~V}^{3}+\mathrm{a}_{4} \mathrm{~V}^{4}+\ldots \ldots
$$

Jika frekuensi masukan adalah $\omega_{1}$ dan $\omega_{2}$, maka frekuensi keluaran akan menjadi $\pm n \omega_{1}$ atau $\pm n \omega_{2}$. Persamaan dibawah ini mengilustrasikan hubungan antara $\omega_{1}$ dan $\omega_{2}$.

$$
\mathrm{V}=\mathrm{A}_{1} \cos \left(\omega_{11} \mathrm{t}\right)+\mathrm{A}_{2} \cos \left(\omega_{2} \mathrm{t}\right)
$$

Maka

$$
\begin{gathered}
I=a 0+a 1\{A 1 \cos (\omega 1 t)+A 2 \cos (\omega 2 t)\} \\
+a 2\left\{\left[A_{1}^{2} \cos 2(\omega 1 t)+A_{2}^{2} \cos 2(\omega 2 t)\right.\right. \\
+A 1 A 2[\cos ((\omega 1+\omega 2) t)+\cos ((\omega 1-\omega 2) t)]\}+\ldots \ldots
\end{gathered}
$$


Persamaan di atas termasuk semua elemen frekuensi dari sinyal keluaran dalam komponen non-linier orde kedua. Gambar 7 menunjukan diagram rangkaian nyata dari mixer dual gate FET. Model dual gate FET adalah 3SK241. $\mathrm{R}_{1}$ dan $\mathrm{R}_{2}$ dalah resistor bias, $\mathrm{C}_{3}$, $\mathrm{C}_{4}, \mathrm{C}_{7}$, dan $\mathrm{C}_{8}$ adalah kapasitor bypass, $\mathrm{L}_{3}$ adalah induktor choke $\mathrm{RF}, \mathrm{C}_{5}, \mathrm{~L}_{4}$, dan $\mathrm{C}_{6}$ adalah low pass filter IF.

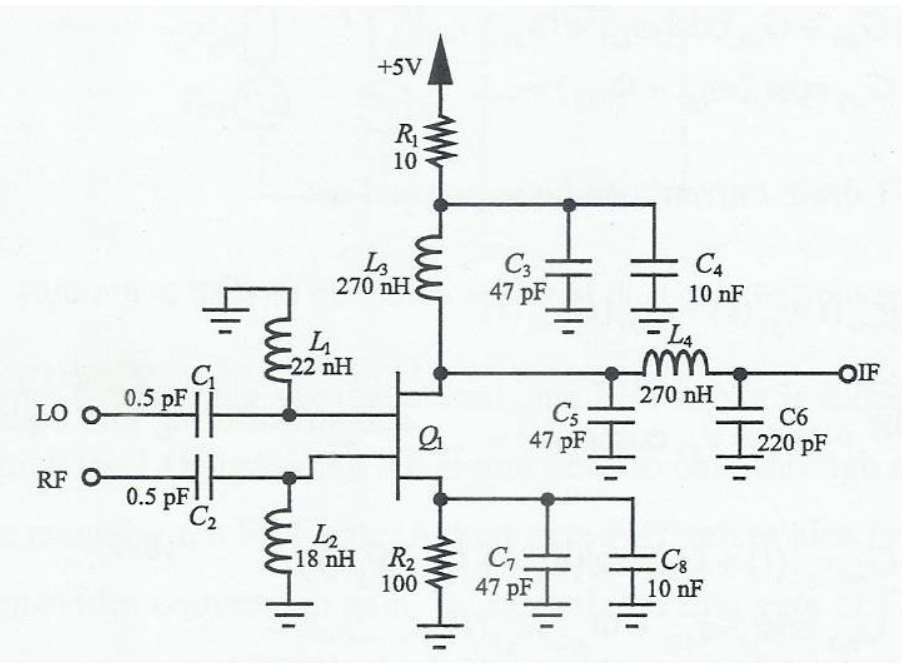

Gambar 7. Diagram rangkaian dari $900 \mathrm{MHz}$ mixer dual gate FET[1]

\subsection{Preamplifier}

Preamplifier adalah rangkaian driver stage dari penguat daya. Tujuan dari preamplifier adalah untuk meningkatkan amplitudo tegangan sinyal $R F$. Penguatan tegangan pada preamplifier lebih diutamakan dari pada penguatan daya. Setelah sinyal frekuensi menengah di transformasikan ke sinyal $R F$, penguat daya mengirim sinyal $R F$ untuk ditransmisikan melalui antena. Gambar 8 berikut adalah rangkaian preamplifier.

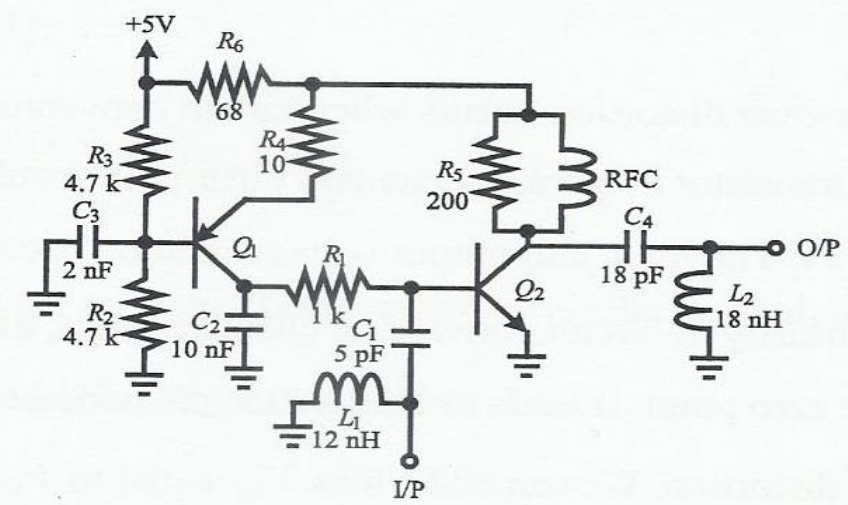

Gambar 8. Diagram rangkaian dari preamplifier active-bias[1]

$\mathrm{R}_{1}, \mathrm{R}_{2}, \mathrm{R}_{3}, \mathrm{R}_{4}, \mathrm{R}_{6}$, dan BJT $\mathrm{Q}_{1}$ meliputi rangkaian aktif-bias untuk BJT $\mathrm{Q}_{2}$; kapasitor $\mathrm{C}_{1}$ dan induktor $\mathrm{L}_{1}$ adalah input matching network; kapasitor $\mathrm{C}_{4}$ dan induktor $\mathrm{L}_{2}$ adalah output matching network. RFC (Radio Frequency Choke) biasa terdapat pada penguat frekuensi tinggi yang berfungsi sebagai peredam frekuensi tinggi yang dihasilkan oleh osilator dan penguat frekuensi tinggi sehingga dapat mencegah timbulnya RFI (Radio Frequency Interference) yang dapat menginterferensi perangkat lain.[3] 


\subsection{Attenuator}

Sebuah attenuator daya adalah sebuah komponen RF yang melemahkan energi. Resistor adalah contoh dari attenuator sederhana, dan jaringan atenuasi dibentuk dari beberapa resistor disebut sum parameter attenuator. Kegunaan attenuator di sini yaitu :

a. Pengatur tingkat daya - memperoleh noise figure optimal dan rugi-rugi konversi frekuensi dari pengaturan daya keluaran akan osilasi lokal dalam penerima.

b. Perangkat pemisah - memisahkan osilator dan beban.

Sebuah attenuator bisa digambarkan seperti jaringan dua port tanpa memperdulikan mekanisme dan struktur, seperti pada Gambar 9. $\mathrm{P}_{1}, \mathrm{P}_{2}, \mathrm{~A}(\mathrm{~dB})$ berdiri sebagai daya sinyal masukan, daya sinyal keluaran, attenuasi daya, secara berurutan. Jika $\mathrm{P}_{1}$ dan $\mathrm{P}_{2}$ dinyatakan dalam satuan $\mathrm{dBm}$, maka relasi secara keseluruhan dapat digambarkan sebagai berikut :

$$
\begin{aligned}
P_{2}(d B m) & =P_{1}(d B m)-A(d B) \\
A(d B) & =10 \log \frac{P_{2}(m W)}{P_{1}(m W)}
\end{aligned}
$$

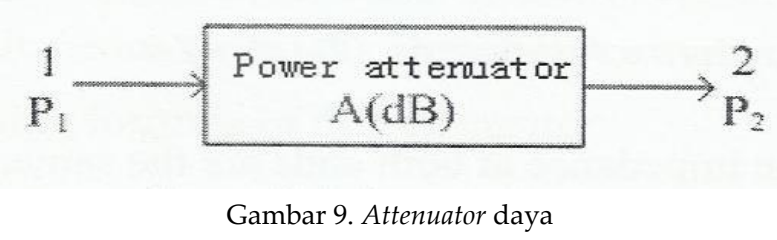

\subsection{Penguat Daya}

Dalam aplikasi komunikasi tanpa kabel (wireless), linearitas dan efisiensi adalah hal utama dari penguat daya. Linearitas menentukan kualitas keluaran sinyal. Efisiensi menentukan daya baterai dan waktu siaga komunikasi. Linearitas dan efisiensi adalah trade-off, jadi kita perlu menjaga keseimbangan untuk memenuhi keluaran yang optimum. Linearitas yang baik dihasilkan oleh penguat kelas A sedang efisiensi yang baik dihasilkan oleh penguat kelas $\mathrm{C}$. Titik kompresi $1 \mathrm{~dB}$ menunjukan penguatan daya batas atas untuk komponen aktif. Dalam titik-titik tertentu, sebagai hasil komponen aktif yang terkena dampak dari linearitas, power gain menjadi lebih rendah dari linearitas sinyal kecil power gain (Go) dari $1 \mathrm{~dB}$. Kita gunakan G1dB untuk mengindikasikan $1 \mathrm{~dB}$ poin kompresi. Hubungan antara linearitas power gain adalah :

$$
\begin{aligned}
G_{1 d B} & =G_{o}(\mathrm{~dB})-1 \\
G_{p w} & =P_{\text {out }} / P_{\text {in }}
\end{aligned}
$$

Ekspresi dalam $\mathrm{dB}$ adalah Pout $(\mathrm{dBm})=\mathrm{Gpw}(\mathrm{dB})+$ Pin $(\mathrm{dBm})$. Gambar 10 menunjukan diagram karakteristik Pout dan Pin.

Tujuan utama penguat daya adalah memperoleh daya keluaran maksimal sehingga bati daya lebih utama dari pada bati tegangan dan penguat daya menggunakan kelas $\mathrm{C}$ agar efisien. Gambar 11 menunjukan $100 \mathrm{~mW}$ penguat daya di $900 \mathrm{MHz}$ pita frekuensi dengan menggunakan BFG540 BJT. R1, R2, adalah resistor bias untuk BJT Q1; kapasitor C1, C2 dan induktor L1 adalah input matching network; kapasitor C5, C6 dan induktor L2, adalah output matching network; C3, C4 adalah kapasitor bypass. Beberapa sistem meminta daya 2 nd order harmonics harus lebih rendah $30 \mathrm{~dB}$ dari daya fundamental. Jadi, kita mungkin membutuhkan untuk merancang sebuah filter 2ndorder harmonics untuk meningkatkan perbandingan antara fundamental dan harmonisa. 


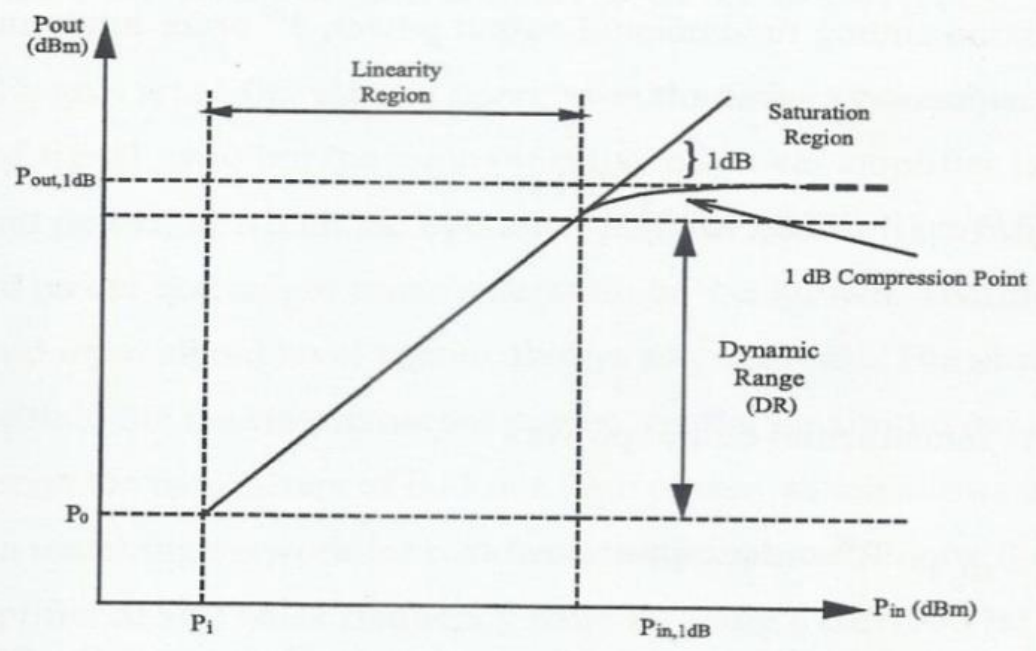

Gambar 10. Definisi dan jarak dinamik dari $1 \mathrm{~dB}$ titik kompresi[2]

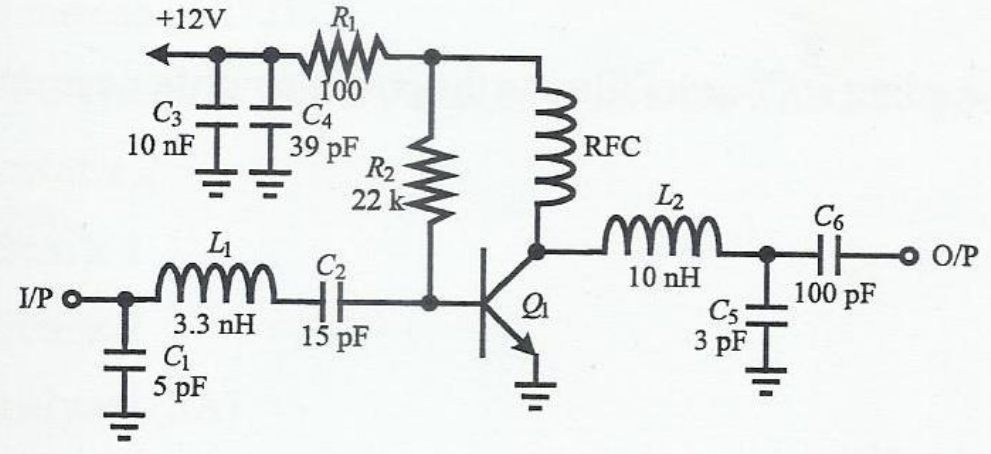

Gambar 11. Diagram rangkaian penguat daya $100 \mathrm{mW[1]}$

\section{Hasil Pengukuran}

\subsection{Modulator}

Dari hasil pengukuran (Gambar 12, 13, 14 \& 15) tampak bahwa dengan perubahan amplitudo pada masukan akan mempengaruhi lebar pita pada keluaran, dimana lebar pita pada amplitudo $1000 \mathrm{mV}_{\mathrm{p}}$ lebih besar dibanding amplitudo $500 \mathrm{mV}$. Semakin besar amplitudo masukan akan menyebabkan semakin lebar lebar pita frekuensinya.

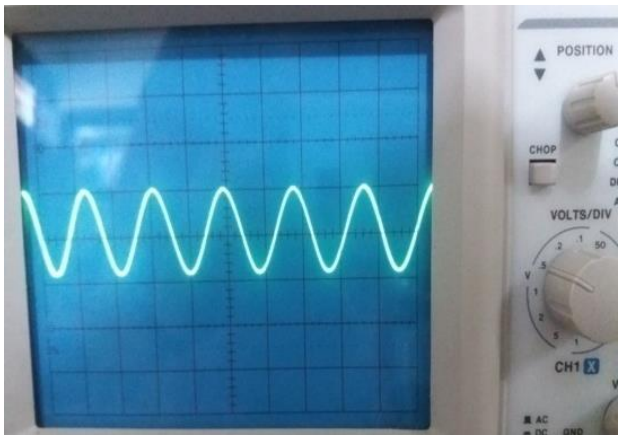

Gambar 12. Masukan 500mV

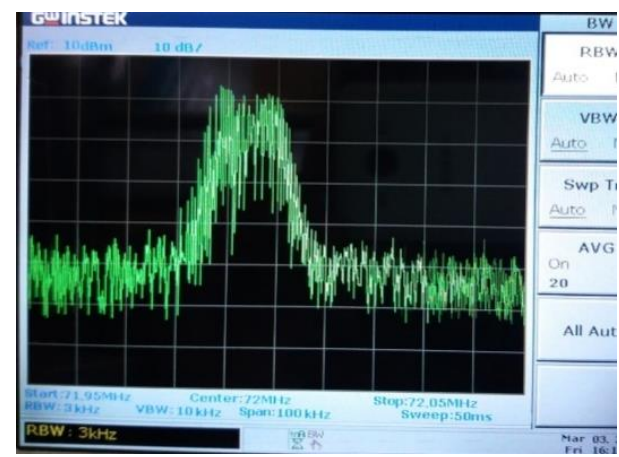

Gambar 13. Keluaran 500mV 


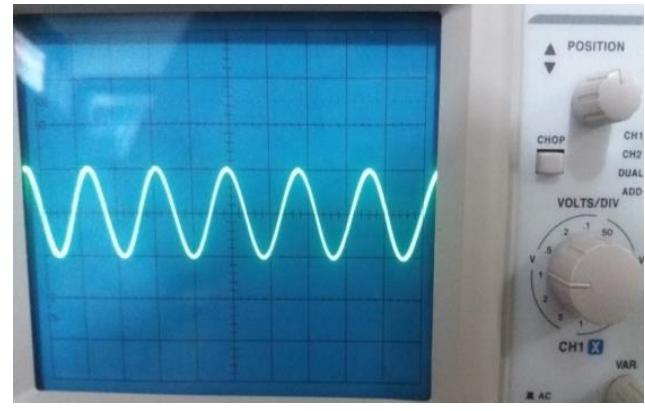

Gambar 14. Masukan $1000 \mathrm{mV} V_{p}$

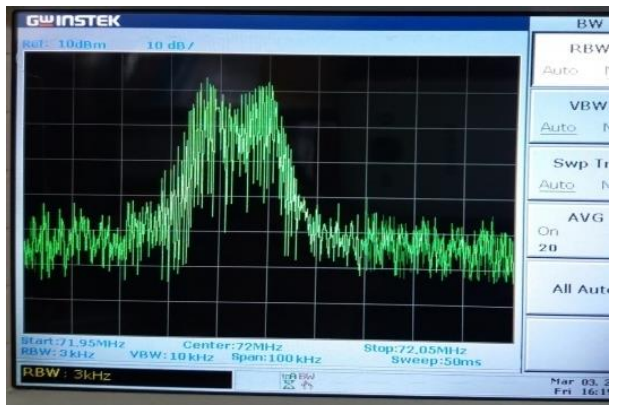

Gambar 15. Keluaran $1000 \mathrm{mV}$ p

\section{2. $\quad$ Mixer}

Dari Tabel 1 bisa kita lihat bahwa mixer ini merupakan jenis down mixer yakni frekuensi pada port IF (Intermediate Frequency) dihasilkan dari frekuensi selisih antara frekuensi $L O$ dan RF. Pada pengukuran conversion loss puncaknya berada pada frekuensi $\pm 70.75 \mathrm{MHz}$. Artinya frekuensi tersebut yang dilewatkan oleh bagian $I F$, sedang selain frekuensi tersebut akan diredam. Jadi dalam hal ini frekuensi pembawa f1= $809.3 \mathrm{MHz}$ yang diterima.

Tabel 1. Hasil mixer

\begin{tabular}{|c|c|c|c|c|c|}
\hline $\begin{array}{c}\mathrm{f} 1(\mathrm{RF}) \\
(\mathrm{MHz})\end{array}$ & $\begin{array}{c}\mathrm{f} 2(\mathrm{LO}) \\
(\mathrm{MHz})\end{array}$ & $\begin{array}{c}\text { Keluaran IF } \\
(\mathrm{MHz})\end{array}$ & $\begin{array}{c}\text { Daya IF } \\
(\mathrm{dBm})\end{array}$ & $\begin{array}{c}\text { Daya RF } \\
(\mathrm{dBm})\end{array}$ & $\begin{array}{c}\text { Conversion } \\
\text { loss (dB) }\end{array}$ \\
\hline 794.3 & 880 & 85.76 & -45.2 & -7 & -38.2 \\
\hline 799.3 & 880 & 80.72 & -42.2 & -7 & -35.2 \\
\hline 804.3 & 880 & 75.72 & -36.2 & -7 & -29.2 \\
\hline 809.3 & 880 & 70.75 & -26.3 & -7 & -19.3 \\
\hline 814.3 & 880 & 65.75 & -28.3 & -7 & -21.3 \\
\hline 819.3 & 880 & 60.75 & -34.3 & -7 & -27.3 \\
\hline 824.3 & 880 & 55.75 & -37.5 & -7 & -30.5 \\
\hline 829.3 & 880 & 50.75 & -40 & -7 & -33 \\
\hline 834.3 & 880 & 45.75 & -40.7 & -7 & -33.7 \\
\hline 839.3 & 880 & 40.75 & -41.8 & -7 & -34.8 \\
\hline 844.3 & 880 & 36.2 & -41.8 & -7 & -34.8 \\
\hline
\end{tabular}

Conversion Loss

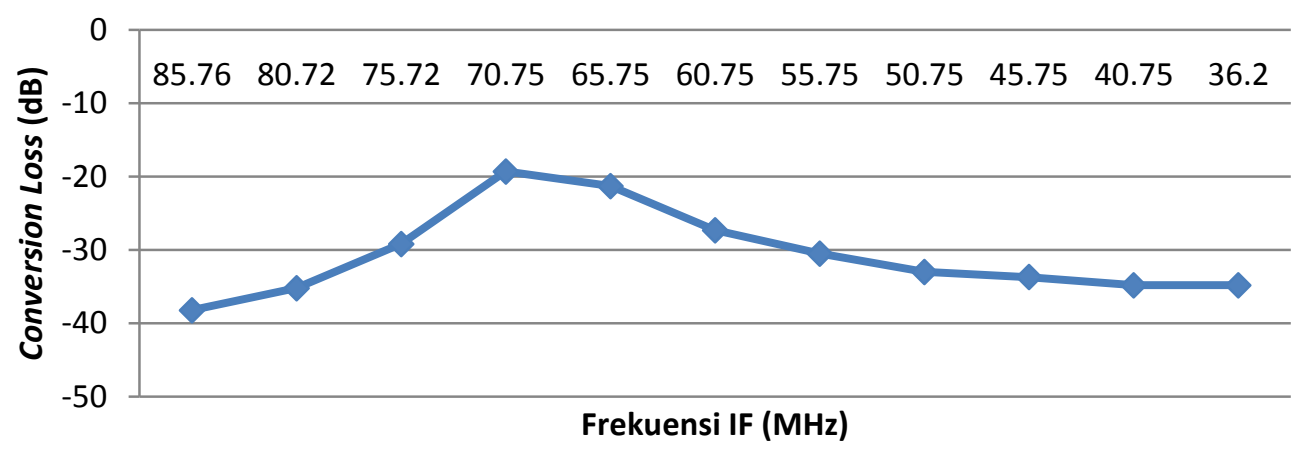

Gambar 16. Grafik conversion loss 


\subsection{Preamplifier}

Untuk masukan yang terlalu kecil tampak penguatan preamplifier belum stabil dan untuk masukan minimal $-25 \mathrm{~dB}$ penguatan daya preamplifier adalah $15 \mathrm{~dB}$ atau 31,6 kali

Tabel 2. Hasil preamplifier

\begin{tabular}{|c|c|c|c|c|c|c|c|c|}
\hline $\begin{array}{c}\text { Masukan } \\
\text { atur }(\mathrm{dBm})\end{array}$ & $<-35$ & -30 & -25 & -20 & -15 & -10 & -5 & 0 \\
\hline $\begin{array}{c}\text { Masukan } \\
\text { Terbaca (dBm) }\end{array}$ & -45 & -45 & -40 & -40 & -30 & -30 & -20 & -20 \\
\hline $\begin{array}{c}\text { Keluaran } \\
\text { Terbaca }(\mathrm{dBm})\end{array}$ & -45 & -35 & -25 & -25 & -15 & -15 & -5 & -5 \\
\hline Gain (dB) & 0 & 10 & 15 & 15 & 15 & 15 & 15 & 15 \\
\hline
\end{tabular}

\section{Daya keluaran}

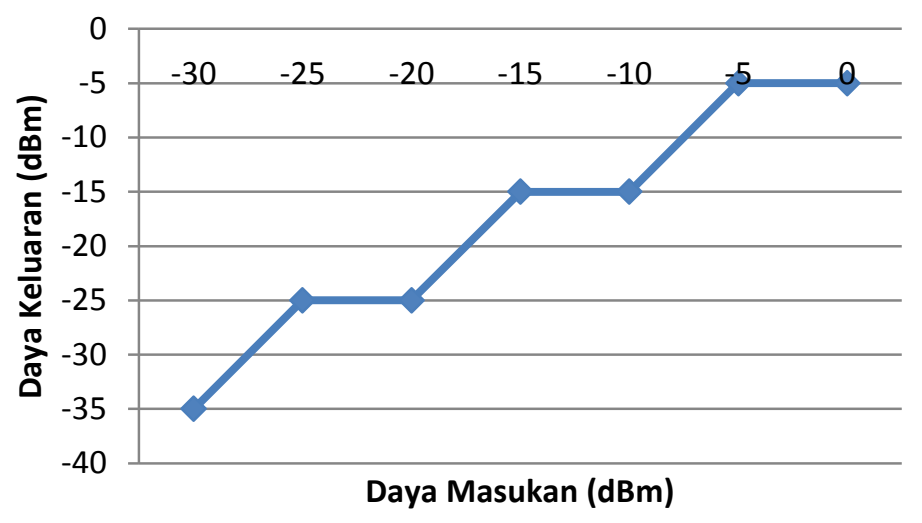

Gambar 17. Grafik hasil preamplifer

\subsection{Attenuator}

Dengan memberikan masukan dan mengukur hasil keluaran pada attenuator $10 \mathrm{~dB}, 5 \mathrm{~dB}$ dan $3 \mathrm{~dB}$ memberikan hasil pelemahan masing-masing sebesar 11,2 dB, 6dB dan 4,1dB. Jadi hasil pada percobaan ini ada perbedaan pelemahan sekitar $1 \mathrm{~dB}$. Hal ini dapat disebabkan penggunaan konektor, jumper atau kabel yang mempunyai pelemahan $1 \mathrm{~dB}$.

Masukan : $-18.8 \mathrm{dBm}$

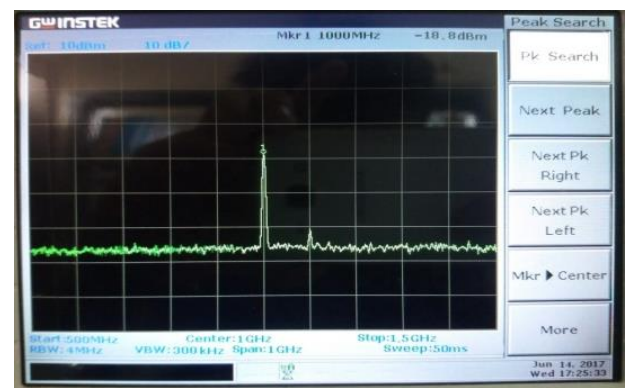

Gambar 18. Masukan attenuator $=-18,8 \mathrm{dBm}$

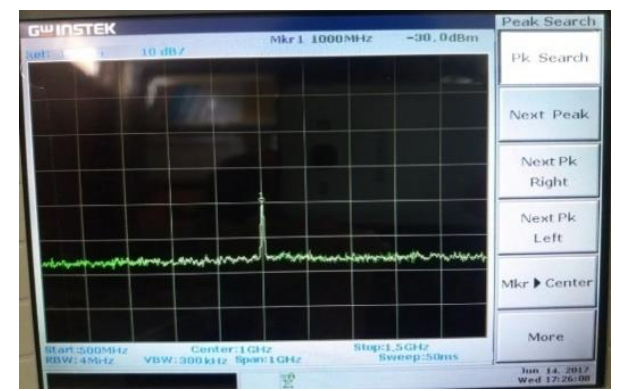

Gambar 19. Keluaran attenuator $10 \mathrm{dBm}=-30 \mathrm{~dB}$ Hasil $A=-30 d B-(-18,8 d B)=-11,2 d B$ 


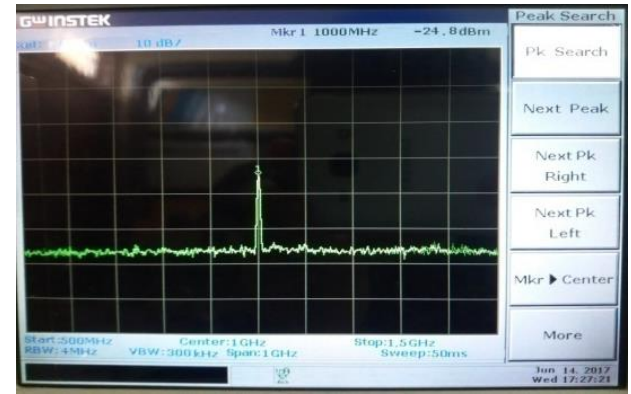

Gambar 20. Keluaran attenuator $5 \mathrm{dBm}=-24,8 \mathrm{~dB}$

Hasil $\mathrm{A}=-24,8 \mathrm{~dB}-(-18,8 \mathrm{~dB})=-6 \mathrm{~dB}$

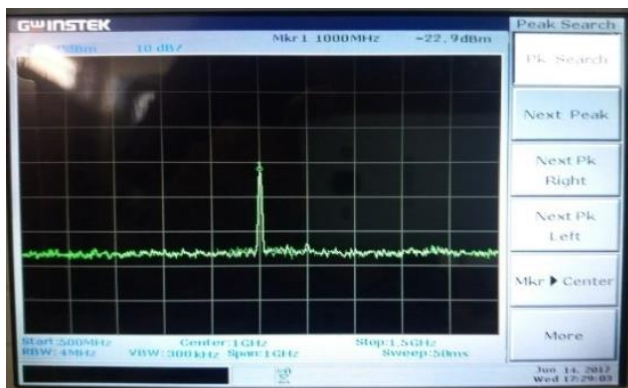

Gambar 21. Keluaran attenuator $3 \mathrm{dBm}=-22,9 \mathrm{~dB}$ Hasil $A=-22,9 \mathrm{~dB}-(-18,8 \mathrm{~dB})=-4,1 \mathrm{~dB}$

\subsubsection{Penguat Daya}

Untuk masukan yang relatip kecil maupun besar penguatan dari penguat daya ini cukup satabil. Dari Tabel 3 dapat dilihat penguatan dari penguat daya ini sekitar $31 \mathrm{~dB}$ atau sebesar 1259 kali.

Tabel 3. Hasil penguat daya

\begin{tabular}{|c|c|c|c|c|c|c|c|c|}
\hline $\begin{array}{c}\text { Masukan atur } \\
(\mathrm{dBm})\end{array}$ & -35 & -30 & -25 & -20 & -15 & -10 & -5 & 0 \\
\hline $\begin{array}{c}\text { Masukan terbaca } \\
(\mathrm{dBm})\end{array}$ & -50 & -50 & -40 & -40 & -30 & -30 & -20 & -20 \\
\hline $\begin{array}{c}\text { Keluaran terbaca } \\
(\mathrm{dBm})\end{array}$ & -18 & -18 & -8 & -8 & 1 & 1 & 10 & 10 \\
\hline Gain (dB) & 32 & 32 & 32 & 32 & 31 & 31 & 30 & 30 \\
\hline
\end{tabular}

\section{Hasil Penguat Daya}

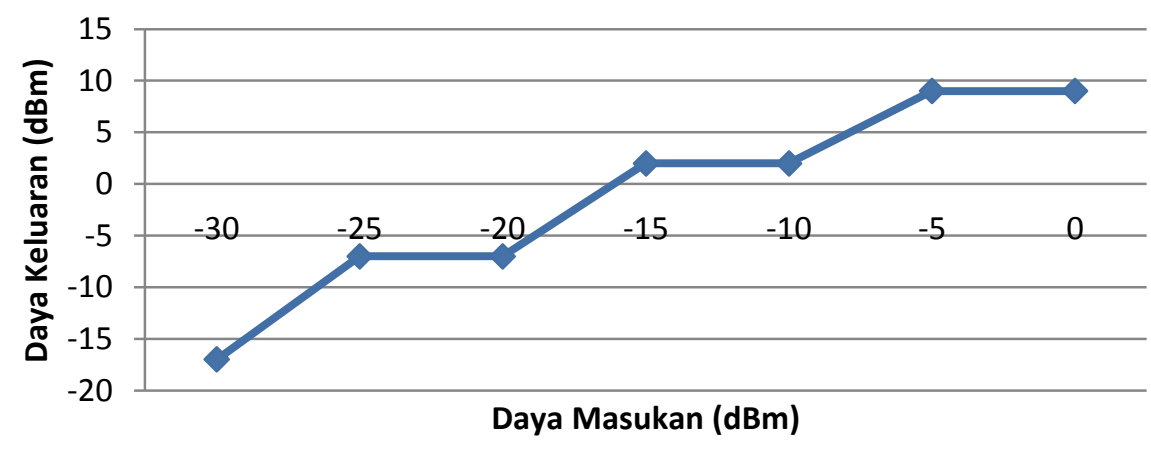

Gambar 22. Grafik hasil penguat daya

\subsection{Transmitter}

Pada modul transmitter ini, kita memberikan masukan berupa sinyal sinus dengan frekuensi $1 \mathrm{KHz}$ dan amplitudo yang diubah. Dari Gambar 23 dan Gambar 24 terlihat hasil keluaran mirip dengan hasil modulasi, tapi pada modul transmitter ini lebih besar karena sudah melewati proses penguatan pada preamplifier dan penguat daya. Pada modul ini juga, kita akan melihat sinyal keluaran pada receiver setelah sinyal dikirim lewat transmitter. Dari Gambar 25 bisa kita lihat, sinyal keluaran receiver yang diamati lewat osiloscope memberikan hasil berupa gelombang sinus. 


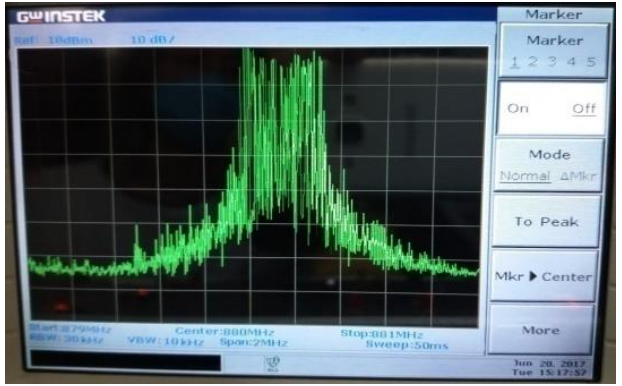

Gambar 23. Keluaran 500mV

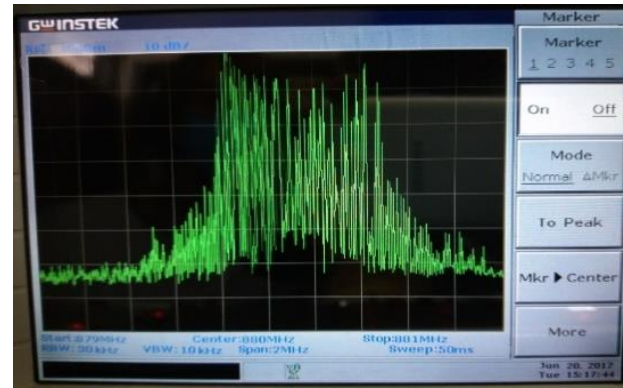

Gambar 24. Keluaran $1000 \mathrm{mV} V_{\mathrm{p}}$

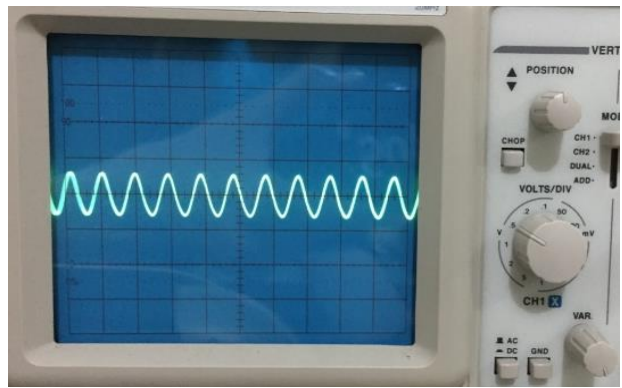

Gambar 25. Keluaran dari reciever

\section{Kesimpulan}

1. Modulasi frekuensi mengubah frekuensi sinyal pembawa (carrier) mengikuti amplitudo pada sinyal masukan dimana kenaikan amplitudo sinyal masukan akan menyebabkan pelebaran spektrum frekuensi sinyal keluaran.

2. Pada percobaan preamplifier mendapatkan hasil penguatan sebesar $\pm 15 \mathrm{~dB}$, atau 31,6 kali. Masukan pada preamplifier tidak boleh terlalu kecil karena akan memperoleh penguatan yang belum stabil. Pada percobaan penguat daya mendapatkan hasil penguatan sebesar $\pm 31 \mathrm{~dB}$ atau 1259 kali. Penguatan pada penguat daya untuk masukan relatip kecil maupun besar adalah cukup stabil. Rangkaian preamplifier dan penguat daya berfungsi dengan baik dan penguatan daya untuk penguat daya adalah jauh lebih besar dari pada preamplifier.

3. Rangkaian attenuator $10 \mathrm{~dB}$ mengalami atenuasi sebesar $11,2 \mathrm{~dB}$, attenuator $5 \mathrm{~dB}$ mengalami atenuasi sebesar $6 \mathrm{~dB}$, attenuator $3 \mathrm{~dB}$ mengalami atenuasi sebesar 4,1 dB. Berdasarkan hasil-hasil percobaan, sinyal keluaran mengalami tambahan atenuasi sekitar $1 \mathrm{~dB}$ yang bisa disebabkan pelemahan konektor, jumper atau kabel yang dipergunakan.

4. Sinyal keluaran mixer dihasilkan dari penjumlahan dan pengurangan antara frekuensi $L O$ dan frekuensi $R F$, tapi karena dalam rangkaian menggunakan filter lewat bawah, maka frekuensi rendah yang dilewatkan. Pada percobaan mixer ini frekuensi pada keluaran sudah tepat, maka mixer sebagai selisih dua frekuensi masukan sudah berfungsi dengan baik.

5. Bentuk sinyal yang diterima receiver sesuai dengan sinyal informasi yang dikirim tranceiver. Jadi sistem komunikasi ini sudah bekerja dengan baik.

\section{Daftar Pustaka}

[1] GWINSTEK, "RF Circuit Training System GRF-3300", Good Will Instrument Co., Ltd. 
[2] Krauss, L.H, Bostian,C.W, Raab,F.H, "Teknik Radio Benda Padat", UI-Press, Jakarta, 1990.

[3] Shrader, Robert L, "Electronic Communication", McGraw-Hill Kogakusha, LTD, edisi ke -4 . 